\title{
Computers and Employment
}

\begin{abstract}
A recent conference in West Germany discussed the effects of advancing technology on employment. Professor L. R. B. Elton, of the Institute for Educational Technology at the University of Surrey, a participant at the conference, has prepared the following report.
\end{abstract}

For some years now, the German Metalworkers' Union (I.G. Metall) has concerned itself with the problems and opportunities that automation and technological progress are bringing to the worker and to the community. This month, Dr G. Friedrichs, director of the division on automation of I.G. Metall, organized the third large international conference in this field, this time on the subject of computers and employment, with special reference to the employment of technicians and other non-manual workers. It took place at Oberhausen in the heart of the Ruhr and was attended by more than 1,000 delegates of whom about 130 came from 22 foreign countries, including the United States and the USSR. Of the 33 main speakers, three were ministers of the German Federal Government and two were high international officials. The rest were divided between academics, employers, workers and trade union officials.

It is probable that nothing much was said at the con. ference that in one way or another was not known before. We heard about the computer explosion, particularly in the United States, and the effect it is having on the employment of workers and operatives. Surprisingly, perhaps, the effect at the technician level has been much less pronounced. This may well be because the advent of a computer in an organization is at first likely to increase the need for technicians, and that at present computers are used mainly for data processing. Once they are used widely for the solution of engineoring problems and problems of design, technicians too will face the need for re-education and re-deployment. On the whole, however, Arnold Weber, professor of industrial relations at Chicago, was reassuring and felt that automation would lead to a redistribution of employment, which could be manageable. This presupposed, however, a generally healthy economy, planned programmes to deal with the problems of shifting workers from one job to another, and a general support and expansion of education.

The need for more and wider education was a recurring theme of the conference and the one that created most passion. Again and again it was stressed that this education had to be general, particularly in mathematics and in the basic sciences, in order to make subsequent reeducation possible. It was interesting that, compared with educational concerns, economic ones seemed to fade into the background as the conference proceeded. It is clear that none of the European countries have found a satisfactory way to combine education and training for those who have left school, and the American solution-to leave students in full-time education for as long as possible through the creation of junior colleges -is not likely to prove economically viable in any other country. Whether it is educationally sound was not discussed.

The structure of the German system of secondary education came in for some hard knocks. At present it is not unlike the tripartite system that was instituted in this country through the 1944 Act, and it was clear that the trade union members of the conference were much in favour of a change towards the comprehensive school. The employers' side seemed decidedly less enthusiastic for change. On the other hand, when it came to content, the recent proposals of the Dainton Committee would merely bring Britain into line with German reforms of the past fow years, which have approached the problem of the swing away from science from the point of under-specialization. An unfortunate consequence of the German reform appears to be that science in the upper school has lost ground in the curriculum compared with the study of languages. The point that a general education in mathematics and science should be part of the curriculum for all for as long as possible was again stressed in a televised discussion on further education and re-education, in which representatives of the Netherlands, Czechoslovakia, Hungary, West Germany and Britain took part. In this discussion, the demand of the I.G. Metall for sabbatical re-education leave for all as of right received qualified, although sympathetic support, but it was accepted that more could not be expected from employers. Employers would, of course, provide courses which were in the direct interests of their concerns, but any wider forms of re-education-and it would have to be wide to be effective-would have to come through government action. In this connoxion the flexible approach of the British technical college received praise.

Another theme that received much attention was the division between white collar and blue collar workers. In the Netherlands this division seems to have largely disappeared, and contributions from both the United States and the United Kingdom stressed that, in the logic of the situation, the divisions are decreasing and will eventually disappear everywhere. But this does not mean that there are not difficulties on the way, and much discussion centred on the problems of those employeers who are not members of a trade union, and are faced with rapidly changing employment conditions, including shift and piecework. Difficulties of a different kind, that face a small socialist country trying to liberalize both its economy and its society, were discussed in a very frank report by Professor Levěík of Cztechoslovakia.

An outstanding and forward looking contribution came from one of Germany's grand old men, Professor Salin, who stressed the need for a management and sociological revolution, without which the technological revolution would be stillborn, and contrasted the American "job" with its built-in flexibility, with the German "Beruf" that concentrated on pension rights. This came at the end of the last day, and was a fitting close to a conference which on the very first day had been aroused by Professor André Philip from France with an impassioned plea to examine "lo sens môme de notre civilization". His peroration included the memorable statement: "mais on ne peut démocratiser les technocrates si l'on n'a pas d'abord technicisé les démocrates".

What was said at this very impressive conference was, however, less important than who had organized it and who took part in it. 'That a trade union had taken the initiative in this field and was co-operating with employers and the government was immensely encouraging, and it was unfortunate that the British trade union movement was not represented. The German I.G. Metall is showing in a very practical way how co-operation on both the national and international planes can be to the benefit of all. The excellence of the contributions of its members illustrated the strength of the union's research effort in this field, and showed that it is taking a responsible attitude towards the problems that are arising for employers and employees, and for society, through the progress of technology. 